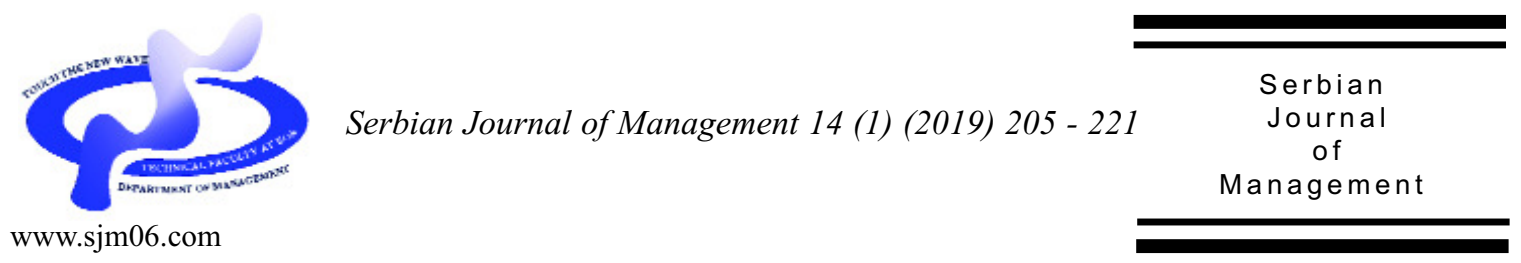

\title{
AN INTEGRATED FRAMEWORK FOR CUSTOMER LOYALTY IN THE HOTEL SECTOR
}

\author{
Elvira Tabaku and Drita Kruja* \\ European University of Tirana, Faculty of Economy and Information Technology, \\ Marketing and Management Department, Bulevardi "Gjergj Fishta", \\ Nd.70, H.1, Tirana, Albania
}

(Received 17 July 2018; accepted 02 April 2019)

\begin{abstract}
This study explores the impact of the antecedents (i.e., service quality, image, trust, perceived value and customer satisfaction) on customer loyalty in the hotel sector.

A total of 361 valid responses from a survey conducted in Albania were received. Data were analyzed using exploratory and confirmatory factor analysis and structural equation modeling. Findings suggest that service quality, image, trust, perceived value and customer satisfaction are reliable predictors of customer loyalty in the hotel sector.

The results of this study can help and guide practitioners in understanding significant elements of their offer toward loyalty creation and reinforcement.
\end{abstract}

Keywords:customer loyalty, service quality, satisfaction, perceived value, image, trust

\section{INTRODUCTION}

The complexity of business environment has challenged companies to implement appropriate marketing strategies. One of these is the strategy based on customer loyalty which enables many benefits especially in situations of high competition and complex environment (Dick \& Basu, 1994; Aydin \& Özer, 2005) as it assists companies in creating the necessary differentiation of their products and services (Russell-Bennett et al., 2007). There are only a few studies that have analyzed customer loyalty and two or three of its antecedents in one model (Kayaman \& Arasli, 2007) while it is necessary to develop an integrated framework for the study of customer loyalty and its antecedents especially in the hotel sector (Martinez \& del Bosque, 2013) and in

\footnotetext{
* Corresponding author: drita.kruja@uet.edu.al
}

DOI: $10.5937 /$ sjm14-18253 
developing countries. If organizations want to increase the loyal behavior of their customers, they must pay attention to the simultaneous management of different aspects of the customer experience (Keiningham et al., 2007) as excellent customer service and customer satisfaction are core competencies of hotel enterprises (Kruja et al., 2016). There is a need to integrate different concepts in a single framework for a better explanation of related consumer behavior but studies examining service quality, customer satisfaction and perceived value altogether were still relatively infrequent in research in general and particularly in tourism and hospitality research over the past 15 years (Haemoon \& Kawon, 2017). There is not an agreed framework about the factors that impact customer loyalty in the marketing literature (Andreassen \& Lindestad, 1998; Lai et al., 2009).

The main objective of this study is to offer an integrated framework of customer loyalty, to examine it and the extent to which the antecedents influence customer loyalty in the hotel sector. It is significant as it provides better understanding on how customer loyalty should be operationalized in the hotel sector and how each antecedent should be used to reinforce it.

\section{LITERATURE REVIEW}

Customer loyalty - Customer loyalty is a complex and difficult construct to define (Salegna \& Goodwin, 2005). One of the most accepted and most referred definitions is the one given by Oliver (1999) who defines customer loyalty as "a deeply held commitment to rebuy or re-patronize a preferred product or service consistently in the future, causing repeated same brand purchasing, despite situational influences and the marketing efforts having the potential to cause switching behavior" (Oliver, 1999). Parasuraman et al., (1985) state that customer loyalty is more dominant in the service sector because of the existence of the interaction provider-customer and because of the higher perceived risk due to the characteristics of the service. Despite that, behavioral intentions and customer loyalty are used less frequently than other ones in the tourism and hospitality studies during the last 15 years (Haemoon \& Kawon, 2017).

Different studies have used different dimensions of customer loyalty conceptualizing it as one dimensional (Kandampully \& Suhartanto, 2000) and more than one dimensional (Jones \& Taylor, 2007; Li \& Petrick, 2008; Singh \& Thakur, 2012). In this study customer loyalty is analyzed as a construct composed by behavioral and attitudinal loyalty as it offers a better explanation of the variable. The dimensionality of customer loyalty is still under investigation and there is not a unanimous accepted agreement related to it (Jones \& Taylor, 2007). This study conceptualizes loyalty as composed of behavioral and attitudinal dimension.

Service quality- Service quality is considered an important mean of differentiation and a significant resource of competitiveness retention (Kotler \& Armstrong, 2013). Zeithaml et al., (1996) define service quality in terms of customer judgments about the general excellence or superiority of a product. Despite the several measurement models, there is no consensus on the best one to use in service quality assessment. Akbaba (2006) states that the absence of exact standards, short supply 
chains, the continuous interaction between employees and customers and the cyclic demand for the service are features that obstruct the measurement of service quality in the hotel sector. The measurement of service quality in this study will be based on the customers' perceptions about it. Despite the studies that have tried to understand the relationship between service quality and customer loyalty (ex. Aydin \& Ozer, 2005; Chen \& Cheng, 2012), the way in which service quality affects the elements of customer loyalty is still unclear (Harris \& Goode, 2004; Clemes et al., 2011). Some studies in the hotel sector have demonstrated positive but not strong relationships between these variables (Gallarza et al., 2013) while other ones (Kim et al., 2008) did not find significant relationships between service quality and customer loyalty. This research aims to empirically analyze this relationship proposing the following hypothesis:

H1. Service quality has a positive direct effect on customer loyalty.

Customer satisfaction - Customer satisfaction is an important element in the development of customers' relations and it is related to the evaluation and the perception of the customers about the ability of a product or service to meet their expectations (Kotler \& Armstrong, 2013).

Customer satisfaction is mostly conceptualized as one dimensional, varying from dissatisfaction to satisfaction (Sánchez et al., 2006) and only a couple of studies have merged the cognitive and emotional dimensions in one single model (Homburg et al., 2006). The cognitive dimension is related to the conceptualization of satisfaction as a function of the comparison expectationperception, while the later one refers to the feelings experienced during the buying or the consumption process (Homburg et al., 2006). Empirical analysis in the tourism industry has showed different results. The study of Skogland and Siguaw (2004) in the hotel sector showed that neither overall satisfaction nor satisfaction with the human factor was determinant of repeated purchases and positive word of mouth while the study of Ryu et al., (2012) showed positive relationship between customer satisfaction and behavioral intentions. Previous research (ex. Harris \& Goode, 2004; Nghiêm-Phú, 2016) state the need of other studies on the relationship between these variables. Based on this fact we pose the second hypothesis, saying that:

H2. Customer satisfaction has a positive direct effect on customer loyalty.

Literature supports the link between service quality and customer satisfaction and some studies (Ladhari, 2009; Nunkoo et al., 2017) have analyzed and supported the direct relationship between these variables, calling for other studies on this relationship. Following theory, we propose a third hypothesis:

H3. Service quality has a direct positive effect on customer satisfaction.

Research on moderation effect is highly desirable as moderators can better explain the nature of the relationship between the independent and dependent variables (Haemoon \& Kawon, 2017). Some studies (Olorunniwo \& Hsu, 2006; Loureiro \& Kastenholz, 2011; Gallarza et al. 2013) analyzed the impact of satisfaction on behavioral intentions and loyalty in the services, stating that beside the direct effect, 
satisfaction serves also as a mediator between service quality and behavioral intentions/loyalty and this effect of quality was even greater than the direct one and called for other studies on this relationship. So, the following hypothesis is proposed:

H4. Customer satisfaction positively mediates the impact of service quality on customer loyalty.

Perceived Value -Perceived value has become one of the most important factors in the success of the production and services organizations (Gronroos, 2011). Zeithaml (1988) sees perceived value as "the overall evaluation of the customer about the usefulness of a product or service based on the perceptions of what is taken and what is given". That served as the base for early studies using only the economic usefulness of value (Zeithaml, 1988). Later ones (Gallarza et al., 2013) have analyzed perceived value from a multidimensional approach (emotional, social value) reflecting a new development of the consumer behavior theory which highlights the significance of the feelings in purchasing and consuming (Sánchez et al., 2006). The relationship between perceived value, other variables and their impact on consumer behavior remains a key issue to study ( $\mathrm{Hu}$ et al., 2009). The construct of perceived value is still unexplored (Chang \& Dibb, 2012) and other studies that incorporate feelings and emotions are needed (Haemoon \& Kawon, 2017). Research (Petrick, 2004; Lai et al., 2009; Chen \& Chen, 2010) has shown that service quality is a good determinant of customer perceived value. However, there has not been found any strong relationships between service quality and perceived value in the tourism industry and in the hotel sector
(Gallarza et al., 2013). So, the following hypothesis is proposed:

H5. Service quality has a positive effect on perceived value.

The empirical literature on the tourism services has shown that perceived value may lead to customer satisfaction (Gallarza and Saura, 2006; Ryu et al., 2012; Gallarza et al., 2013) while other studies (Yang \& Peterson, 2004; Chen, 2008) assessed that perceived value has a direct positive effect on customer satisfaction although. Despite the lack of consensus in literature on this issue, (Gallarza et al., 2013), we propose the following hypothesis:

H6. Perceived value has a direct positive effect on customer satisfaction.

Some studies (Gallarza \& Saura, 2006; Chen \& Cheng, 2012) showed that perceived value has a direct effect on customer loyalty while other ones (Chen \& Tsai, 2007; Flint et al., 2011) argued that perceived value did not impact customer loyalty. Based on this analyze the following hypothesis is proposed:

H7. Perceived value has a direct positive effect on customer loyalty.

Image - The image of a business is an important variable that may significantly impact its marketing activities, customers' buying behavior and customer loyalty (Nguyen \& LeBlanc, 2001; Kandampully \& $\mathrm{Hu}, 2007)$. Different researchers have defined the image of an organization as something that comes in customers' mind when they hear the name of the organization (Nguyen, 2006) and as the element that 
describes customers' thoughts and feelings about it (Lee et al., 2011). The image of the business is thought to be composed of two dimensions: the functional or cognitive dimension and the emotional one (San Martin \& delBosque, 2008; Giraldi \& Cesareo, 2014). The functional dimension concerns the physical attributes and can be measured easily, while the emotional one refers to the psychological aspects that are manifested in feelings and attitudes toward the organization as a result of the experience with it. Image can play a strong impact on buyers' decision and their repurchase behavior, being so a significant element for customer loyalty (Nyadzayo \& Khajehzadeh, 2016; Biscaia et al., 2017). Ryu et al. (2012) evidenced that limited research has investigated image and its outcome variables such as perceived value and behavioral intentions in an integrative model in the tourism industry. As tourism services are intangible, the image of the business becomes more important than the reality (Gallarza et al., 2002). Studies in different sectors of the economy have shown the existence of the link between service quality and organization image. Some studies (Kandampully \& Suhartanto, 2000; Aydin \& Özer, 2005) stated that service quality has a positive effect on customer perceptions. Kayaman and Arasli (2007) after the analysis on the hotel sector declared that image stems from the customer experience with the hotel and perceived service quality is a function of this consumption experience. Based on the above-mentioned, the following hypothesis is proposed:

H8. Service quality has a positive direct effect on hotel image.

The impact of organization image may lead the customer to repeat purchases (Dick \& Basu, 1994) and may positively impact the intentions to behave (Nadiri et al., 2008). Researchers (Kandampully \& Suhartanto, 2000; Ladhari et al., 2011) have noticed that organization image may have a strong impact on customer decision to repurchase. Based on these arguments the following hypothesis is proposed:

H9. Hotel image has a positive direct effect on customer loyalty.

Few studies (ex. Lai et al., 2009; Ryu et al., 2012) have analyzed the direct relationship between image and perceived value. The study of Brown and Mazzarol (2009) indicated that image does not have a direct effect on customer loyalty but it has a strong effect on perceived value. Based on these arguments this hypothesis is proposed:

H10. Hotel image has a positive effect on perceived value.

Trust - Trust has become an important element in marketing activities having a key role in creating and maintaining long term relationships (Morgan \& Hunt, 1994) particularly in the service sector where the services are bought and then are consumed. Different studies (ex. Hong \& Cho, 2011; Martinez \& delBosque, 2013) view trust as composed of competence, benevolence and integrity dimensions. Trust is very important in the hotel sector because it is not easily copied and it assists the hotel in the differentiation from the competitors (Bowen \& Shoemaker, 1998). Some studies (Singh \& Sirdeshmukh, 2000; Gounaris, 2005) stressed that service quality may be an important determinant of it and this effect of service quality on trust should be greater and 
more valuable on the service environment. shown that trust is directly and positively Based on these arguments from different affected by customer satisfaction. While, sectors the following hypothesis is proposed:

H11. Service quality has a positive effect on customer trust about the hotel.

Some researchers (Singh \& Sirdeshmukh, 2000; Agustin \& Singh, 2005; Aydin \& Ozer, 2005) have analyzed the relationship between satisfaction and trust. They have the hotel.

(2005) proposed that brand trust stems from the prior experience and is a result of overall satisfaction. Based on these arguments the following hypothesis is proposed:

H12. Customer satisfaction has a direct and positive effect on customer trust about

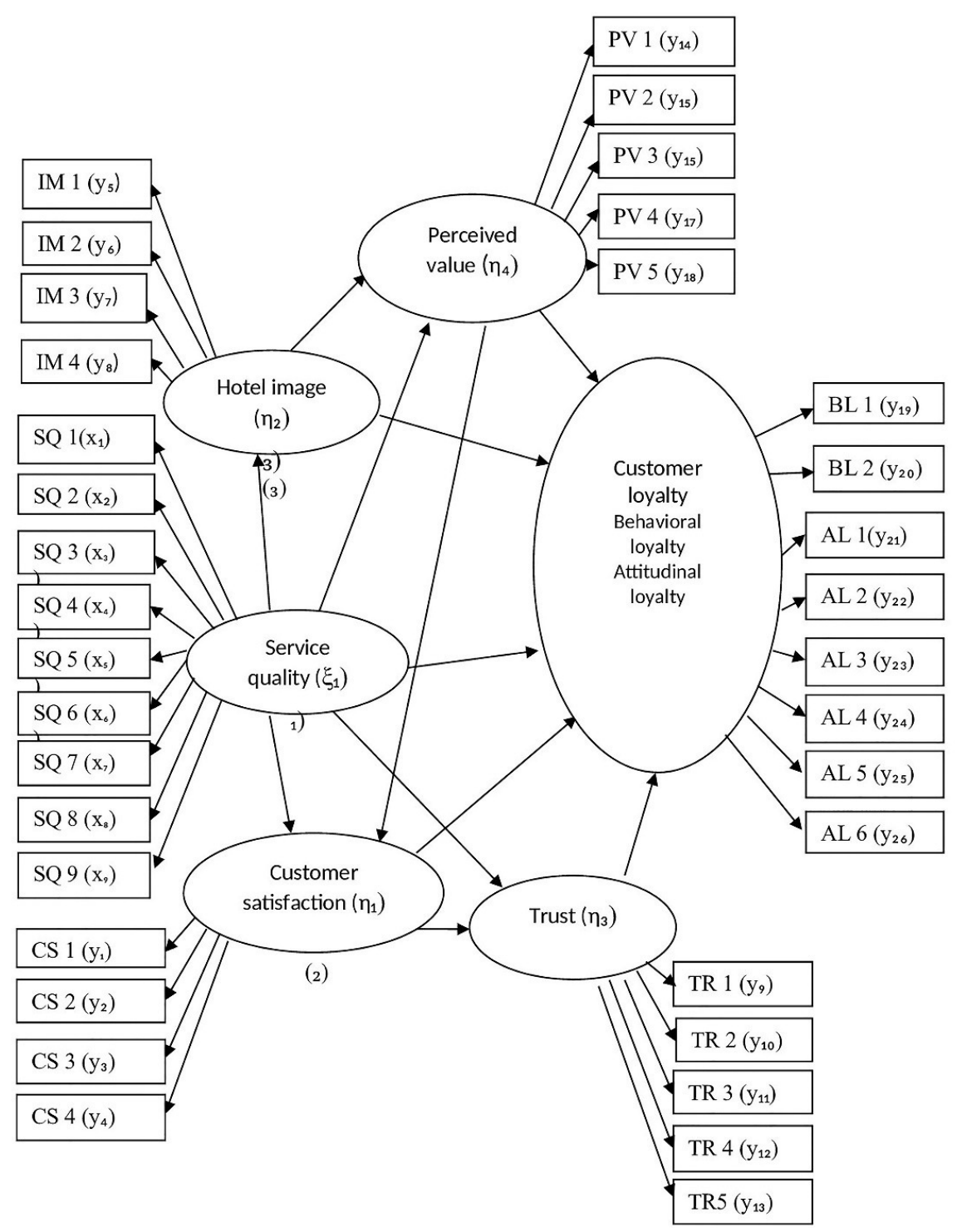

Figure 1. Conceptual Model 
Some studies (Hong \& Cho, 2011; Laroche et al., 2013; Martinez \& delBosque, 2013) have demonstrated that there are significant and direct relationships between trust and intentions to repurchase and the influence of trust on loyalty in the hotel sector was either stronger than the effect of customer satisfaction (Martinez \& delBosque, 2013). Based on this analyze the following hypothesis is developed:

H13. Trust on the hotel has a positive effect on customer loyalty.

Based on the literature review, the conceptual model is proposed, Figure 1.

\section{METHOD}

\subsection{Measurement Instrument}

The measurement of customer loyalty in this study is based on behavioral and attitudinal loyalty and the items are adapted from previous studies (Dick \& Basu, 1994; Zeithaml et al., 1996; Petrick, 2004; Skogland \& Siguaw, 2004; Parasuraman et al., 2005; Russell-Bennet, et al., 2007; Li \& Petrick, 2008).

Service quality is measured as a variable composed of five dimensions: tangibility, reliability, responsiveness, assurance and empathy. These items are developed based on the studies of Parasuraman et al. (1985), Kayaman and Arasli (2007), Nadiri, et al., (2008), Pantouvakis and Lumperopoulos (2008), Nam et al. (2011). This study assessed customer satisfaction by evaluating total satisfaction, the comparison expectation-perception, and satisfaction with the decision taken to buy the service, emotional satisfaction and the comparison with other service offers. Perceived value is assessed through items of overall value, the functional, emotional and social value adapted from the study of Zeithaml (1988), Sirdeshmukh et al. (2002), Sánchez et al. (2006), and Gallarza et al. (2013). Whereas image is assessed using items adapted from the study of Kandampully and Suhartanto (2000), Nguyen and LeBlanc (2001), Del Bosque and Martin (2008), and Ladhari et al., (2011) The item scale for measuring customers' trust in the hotel sector is based on the study of Chaudhuri and Holbrook (2001), Martinez and delBosque (2013) and Sirdeshmukh et al. (2002). A Likert-5 scale is used to measure the approval/disapproval of the hotel customers with each of the measurement items. The questionnaire consisted of 36 items.

The draft questionnaire was analyzed from two marketing and tourism academics and two hotel administrators. This procedure ensured the questionnaire's content validity and helped on the definition of an adequate instrument for the Albanian context. Also several questions describing the demographic profile of the respondents were used.

\subsection{Sampling and Data Collection}

The study was concentrated in the three main districts of the country, such as: Vlora, Shkodra and Durrës, in four and three star hotels. The districts were chosen as principal sun and sand tourism areas. Attention in sampling is given to the number of rooms occupied in each of the 66 hotels. The definition of the size of the sample is conducted based on the type of the study and the way of data processing, so the statistical method used (Hair et al., 2009). The literature ( Hair et al., 2009; Bagozzi \& Yi, 
2012) suggests that a number of 200 to 400 subjects are needed in the researches where the opinion of the respondents about their thought and perceptions is asked. Therefore, a sample of 400 was deemed appropriate for this study. 5 interviewers with prior experiences with similar surveys helped with questionnaire completion. A total of 361 questionnaires were returned completed resulting in a response rate of $91 \%$.

\section{RESULTS}

\subsection{Profile of Survey Respondents}

$52 \%$ of participants were male and the average age was 43 years. The majority of

\section{Table 1. Reliability coefficients of the scale}

\begin{tabular}{|c|c|c|}
\hline Construct/Items & $\begin{array}{l}\text { Cronbach's } \\
\text { alpha }\end{array}$ & $\begin{array}{l}\text { Item } \\
\text { loadings }\end{array}$ \\
\hline Service quality - SQ & 0.786 & \\
\hline The hotel is visually appealing & & 0.716 \\
\hline The facilities of the hotel are modern & & 0.749 \\
\hline The hotel staff provides timely and quality service & & 0.827 \\
\hline The hotel offers stable quality service & & 0.811 \\
\hline The hotel staff performs the right service & & 0.828 \\
\hline The hotel staff is always willing to help clients & & 0.720 \\
\hline The hotel staff is courteous & & 0.744 \\
\hline The hotel staff is trustworthy & & 0.816 \\
\hline The hotel staff offers personalized services & & 0.708 \\
\hline Customer satisfaction - CS & 0.752 & \\
\hline Overall, I am very satisfied with the services offered by the hotel & & 0.758 \\
\hline I am satisfied with my decision to stay at this hotel & & 0.733 \\
\hline Overall, the service offered at this hotel meets my expectations & & 0.744 \\
\hline Compared to other hotels I've stayed in I'm very satisfied with this hotel & & 0.706 \\
\hline Perceived value - PV & $\mathbf{0 . 8 2 8}$ & \\
\hline $\begin{array}{l}\text { The service I receive from this hotel is better in comparison to other places I } \\
\text { have stayed }\end{array}$ & & 0.857 \\
\hline Overall, the price is fair for the performance I receive at this hotel & & 0.808 \\
\hline The service of this hotel is good value for money & & 0.776 \\
\hline Staying at this hotel makes me feel good & & 0.846 \\
\hline The fact that I frequent this hotel makes a good impression on other people & & 0.788 \\
\hline Image-IMA & 0.793 & \\
\hline The hotel has a good image in the mind of customers & & 0.722 \\
\hline This hotel has a unique image & & 0.762 \\
\hline The hotel is conveniently located & & 0.749 \\
\hline I have a good impression of this hotel & & 0.765 \\
\hline Trust-TR & $\mathbf{0 . 7 3 9}$ & \\
\hline I could rely on the hotel to solve my complaints (during my stay) & & 0.728 \\
\hline I feel safe in this hotel & & 0.711 \\
\hline Employees provide quick and correct answers & & 0.757 \\
\hline This hotel pas interest to its clients during their stay & & 0.800 \\
\hline This hotel is honest with its clients & & 0.749 \\
\hline Customer loyalty - CL & 0.791 & \\
\hline Compared to other hotels in this area, I have stayed more in this hotel & & 0.792 \\
\hline I have stayed in this hotel when visiting this area in the last years & & 0.784 \\
\hline I always stay in this hotel & & 0.764 \\
\hline I intent to frequent this hotel in the near future & & 0.817 \\
\hline $\begin{array}{l}\text { As long as I travel to this area, I do not foresee myself switching to a different } \\
\text { hotel }\end{array}$ & & 0.733 \\
\hline I would say positive things about the hotel to other people & & 0.748 \\
\hline I would highly recommend the hotel to my friends and family & & 0.719 \\
\hline I would encourage my friends or relations to visit this hotel & & 0.734 \\
\hline If the hotel were to raise the price of my stay, I would still continue to be a guest & & 0.756 \\
\hline Scale reliability & 0.814 & \\
\hline
\end{tabular}


them (89\%) were from Albania and 11\% Albanians who live in neighbor countries. The sample is in accordance with the population. $47 \%$ of participants had an annual personal income between $\$ 8000$ 11.600 and $30 \%$ more than $\$ 15.400$. $72 \%$ of participants were married with children and $46 \%$ of them had undergraduate and postgraduate education.

\subsection{Testing of the Measurement Model}

Data analysis started with the assessment of the data in order to find out if they were valid to be submitted to the statistical analysis. These data were submitted to the control for missing data, outliers, normality and linearity. The missing data were replaced using multiple imputation method. The values were within the excepted ranges and resulted only in linear relationships.

After that, the Confirmatory Factor Analysis - CFA was conducted to further assess the reliability, validity and the dimensionality of the measurement scale. The values of Cronbach's alpha demonstrated good internal sustainability of the items of the constructs and reliability of the constructs as they varied from 0.706 to 0.857 as shown in Table 1 . Construct and convergent validity were calculated using the ro $(\rho)$ coefficient (Croteau \& Li, 2003) and the values were greater than 0.70 showing good validity. Discriminant validity was tested by means of two methods. One of them is the Average Variance ExtractedAVE. The calculated values of AVE were greater than 0.50 proving discriminant validity. These values are shown in the Table 2.

The second measurement method was based on the test of the differences of the chi squared of the restricted model and their correspondents in the unrestricted one by means of the CHIDIST function in MS Excel. All the differences (chi squared of the

Table 2. Indicators of composite reliability and convergent validity for the models' constructs

\begin{tabular}{lccc}
\hline Construct & Number of items & $\begin{array}{c}\text { Composite reliability } \\
\left(\rho \text { or } \mathrm{r}_{\mathrm{o}}\right)\end{array}$ & $\begin{array}{c}\text { Average Variance } \\
\text { Extracted - AVE }\end{array}$ \\
\hline Service quality & 9 & 0.841 & 0.751 \\
Customer satisfaction & 4 & 0.951 & 0.558 \\
Image & 4 & 0.741 & 0.715 \\
Perceived value & 5 & 0.778 & 0.695 \\
Trust & 5 & 0.905 & 0.641 \\
Customer loyalty & 9 & 0.841 & 0.847 \\
\hline
\end{tabular}

Table 3. Control of discriminant validity through the test of the differences of the chi squared

\begin{tabular}{lllllll}
\hline & SQ & CS & IM & PV & TR & CL \\
\hline Service quality & 1.000 & & & & & \\
Customer satisfaction & 0.278 & 1.000 & & & & \\
Image & 0.210 & 0.338 & 1.000 & & & \\
Perceived value & 0.045 & 0.316 & 0.181 & 1.000 & & \\
Trust & 0.211 & 0.301 & 0.144 & 0.276 & 1.000 & \\
Customer loyalty & 0.164 & 0.397 & 0.156 & 0.247 & 0.324 & 1.000 \\
\hline
\end{tabular}


restricted model - chi squared of unrestricted model) were significantly high. The results are presented in Table 3.

The presented tests and the estimates of reliability with Cronbach's alpha showed acceptable levels of reliability, content validity, intern validity, convergent and discriminant validity. Therefore, the measure scale was considered valid to continue the further testing of the proposed model.

\subsection{Testing of the Structural Model}

After that, Structural Equation Modeling SEM was conducted. Following the recommendations of Hair et al. (2009), the data analysis of this study was done in two separate stages. Both, measurement and structural models were explored for the proposed model. Another important analysis was the assessment of the overall fit, which determined the correspondence between observed model and the estimated one (the proposed model developed from literature review). The method used in this study was the one of multiple fit indices classified in absolute, incremental and parsimony fit indices (Hair et al., 2009). The fit indices which assessed the proposed model resulted in these values: $\chi^{2}=347.18(\mathrm{df}=630)$, GFI $=0.95, \mathrm{AGFI}=0.97, \mathrm{RMSEA}=0.05$, $\mathrm{SRMR}=0.042, \mathrm{NNFI}=0.92, \mathrm{CFI}=0.98, \mathrm{IFI}$ $=0.917, \mathrm{PGFI}=0.906$. Their values exceed the border ranges showing that the model had good fit.

The next step concerned the test of the proposed model and the hypothesis. This test was based on parameter estimates. The results are presented in the Table 4.

\section{DISCUSSION}

This research offered a comprehensive review of the existing literature on different variables of marketing and consumer behavior, showing that relationships between variables may not always exist. By exploring these variables it offered a conceptual model

Table 4 The results of path analysis for the hypothesis of the study

\begin{tabular}{llll}
\hline Hypothesis & $\begin{array}{l}\text { Standard sized path } \\
\text { coefficients }\end{array}$ & $\begin{array}{l}\text { Statistical } \\
\text { significance }\end{array}$ & $\begin{array}{l}\text { Hypothesis } \\
\text { testing }\end{array}$ \\
\hline $\mathrm{H} 1: \mathrm{SQ} \rightarrow \mathrm{CL}$ & 0.33 & 0.002 & Supported \\
$\mathrm{H} 2: \mathrm{CS} \rightarrow \mathrm{CL}$ & 0.44 & 0.000 & Supported \\
$\mathrm{H} 3: \mathrm{SQ} \rightarrow \mathrm{CS}$ & 0.33 & 0.000 & Supported \\
$\mathrm{H} 4: \mathrm{SQ} \rightarrow \mathrm{CS} \rightarrow \mathrm{CL}$ & 0.15 & & Supported \\
$\mathrm{H} 5: \mathrm{SQ} \rightarrow \mathrm{PV}$ & 0.37 & 0.001 & Supported \\
$\mathrm{H} 6: \mathrm{PV} \rightarrow \mathrm{CS}$ & 0.28 & 0.004 & Supported \\
$\mathrm{H} 7: \mathrm{PV} \rightarrow \mathrm{CL}$ & 0.27 & 0.008 & Supported \\
$\mathrm{H} 8: \mathrm{SQ} \rightarrow \mathrm{IM}$ & 0.29 & 0.000 & Supported \\
$\mathrm{H} 9: \mathrm{IM} \rightarrow \mathrm{CL}$ & 0.44 & 0.001 & Supported \\
$\mathrm{H} 10: \mathrm{IM} \rightarrow \mathrm{PV}$ & 0.31 & 0.001 & Supported \\
$\mathrm{H} 11: \mathrm{SQ} \rightarrow \mathrm{TR}$ & 0.24 & 0.003 & Supported \\
$\mathrm{H} 12: \mathrm{CS} \rightarrow \mathrm{TR}$ & 0.41 & 0.001 & Supported \\
$\mathrm{H} 13: \mathrm{TR} \rightarrow \mathrm{CL}$ & 0.42 & 0.001 & Supported \\
\hline
\end{tabular}


of their possible relationships, assessing it on the hotel sector in Albania. It proposed customer loyalty as a dependent variable impacted by different antecedents; service quality, customer satisfaction, perceived value, image and trust. The complexity of the variables and their inclusion in one model is particularly relevant in the tourism industry. Contrasting prior studies that proposed and assessed two or three independent variables of loyalty, this study aimed to offer a more complete model by putting in the same frame all the supposed prerequisites of loyalty as they actually impact in reality, simultaneously. The analysis found all of them statistically significant. The results showed that service quality was a significant determinant of customer satisfaction, perceived value, image and trust which all positively impacted customer loyalty.

Service quality was also found to have a direct positive effect on customer loyalty reinforcing its role on the model of customer loyalty. Customer satisfaction was found to have a positive direct effect on trust and loyalty. Despite the direct effect on customer loyalty, customer satisfaction was found to be a good mediator of service quality on customer loyalty, reinforcing its role on loyalty and in this model. The results of the analysis support the relationship between image of the hotel and customer loyalty and between image and perceived value. Trust resulted to have a positive direct effect on customer loyalty Moreover, trust and image served also as mediators between service quality and customer loyalty while perceived value mediated the effect of image on customer satisfaction. These results reinforce the role of the variables included in the model of customer loyalty as they resulted to have positive and significant effect on customer loyalty both direct and moderate.

\subsection{Implications}

Theory implications - The present study makes several significant theoretical contributions to the hospitality industry. The study offered an approach of the customer loyalty in the B2C marketing in the hotel sector. It assessed and reinforced the conceptualization of customer loyalty as a multidimensional construct. Another significant implication is the validation of customer loyalty in the hotel sector of a developing country. It developed a theoretical model which served as an instrument for assessing customer loyalty in the hotel sector. The model and the instrument can be used in other sectors with the appropriate modifications.

The study offered a thorough understanding of customer loyalty and its determinants. There are no similar studies that incorporate the variables of service quality, image, trust, perceived value, customer satisfaction and customer loyalty as simultaneously composed of different dimensions each and in one conceptual model. It showed that it is of great significance the inclusion of all the factors in one single model when developing a critical analyze of customer loyalty.

Practical implications -This study analyzed variables that are considered of great importance for every business and particularly in the tourism industry. The application of this model was empirically analyzed in the hotel sector. Marketers and managers in the hotel sector must be aware of the necessity of creating and maintaining customer loyalty as an important determinant of profitability and sustainable development. There are no similar studies that incorporate all these variables so this study offers a significant practical contribution. 
Another key implication is the offering of empirical data with hotel customers so the results of the study are very significant for the managers, administrators and owners in this sector. They can have a better understanding of what creates and reinforces each of the variables. They must dedicate specific focus to each dimension of service quality. The combination of all of these elements of the hotel service can bring the customers to meet and exceed their expectations, to create and reinforce their satisfaction. By improving the overall impression, image and trust managers can create positive feelings that lead also to customer loyalty.

Managers should try to create a good and unique atmosphere in order to create positive image of the hotels to customers and instill customer trust. Based on this knowledge, hotels can create an important marketing strategy and a competitive advantage for their businesses.

Meanwhile, the institutions that operate in tourism industry and particularly in the hotel sector are given an important mean in order to orientate their politics for having a sustainable development in this sector. These institutions should design adequate politics in the sector. As part of the entire network they should orient and manage the policies of the tourism industry and hotel sector toward the most important factors of the tourism offer as the ones analyzed in this study.

\subsection{Limitations of the study}

Firstly, the typology of the hotels analyzed in the study was hotels of the sun and sand segment while there are other kinds of hotels. Even though this sector is the biggest hotel service in Albania, this may limit the representativeness. Said this, it would be of interests to conduct the same study, targeting other hotels 'services.

Secondly, the analysis of the construct of customer loyalty from both customers and management point of view could add information in the way providers and customers perceive hotel services and can help management on a better understanding of the customers' perceptions. This way, they can understand and evaluate similarities and gaps on the understanding of loyalty from both perspectives and engage on closing these gaps.

\section{References}

Agustin, C., \& Singh, J. (2005). Curvilinear effects of customer loyalty determinants in relational exchanges. Journal of Marketing Research, 42 (1), 96-108.

Akbaba, A. (2006). Measuring service quality in the hotel industry: A study in a business hotel in Turkey. Hospitality Management, 25 (2), 170-192.

Andreassen, T.W., \& Lindestad, B. (1998). Customer loyalty and complex services: The impact of corporate image on quality, customer satisfaction and loyalty for customers with varying degrees of service expertise. International Journal of Service Industry Management, 9 (1), 7- 23.

Aydin, S., \& Özer, G. (2005). The analysis of antecedents of customer loyalty in the Turkish mobile telecommunication market. European Journal of Marketing, 39 (7/8), $910-925$.

Bagozzi, R.P., \& Yi, Y. (2012). Specification, evaluation and interpretation of structural equation models. Journal of the Academy of Marketing Science, 40 (1), 834.

Biscaia, A.R., Rosa, M.J., Moura e Sá, P., 


\section{ИНТЕГРИСАНИ ОКВИР ЗА ЛОЈАЛНОСТ КЛИЈЕНАТА У ХОТЕЛСКОМ СЕКТОРУ}

\section{Elvira Tabaku, Drita Kruja}

\section{Извод}

Ова студија истражује утицај претходних услова (тј. квалитета услуга, имиџа, поверења, опажене вредности и задовољства клијената) на лојалност клијената у хотелском сектору.

Укупно је примљен 361 валидан одговор у истраживању спроведеном у Албанији. Подаци су анализирани коришћењем експлоративне и конфирмативне факторске анализе и моделирања структурних једначина. Налази указују да су квалитет услуге, имиџ, поверење, уочена вредност и задовољство клијената поуздани предиктори лојалности клијената у хотелском сектору.

Резултати ове студије могу помоћи и упутити практичаре у разумевање значајних елемената њихове понуде за стварање и јачање лојалности.

Кључне речи: лојалност потрошача, квалитет услуге, задовољство, опажена вредност, имиџ, поверење

\& Sarrico, C.S. (2017). Assessing customer satisfaction and loyalty in the retail sector. International Journal of Quality \& Reliability Management, 34 (9), 1508-1529.

Bowen, J.T., \& Shoemaker, S. (1998). The antecedents and consequences of customer loyalty. Cornell Hotel and Restaurant Administration Quarterly, 39 (1), 12-25.

Brown, R.M., \& Mazzarol, T.W. (2009). The importance of institutional image to student satisfaction and loyalty within higher education. Higher Education, 58 (1), 81-95.

Chang, C., \& Dibb, S. (2012). Reviewing and conceptualizing customer-perceived value. The Marketing Review, 12 (3), 253274.

Chaudhuri, A., \& Holbrook, M.B. (2001). The chain of effects from brand trust and brand affect to brand performance: the role of brand loyalty. Journal of Marketing, 65 (2), 81-93.

Chen, C.F. (2008). Investigating structural relationships between service quality, perceived value, satisfaction, and behavioral intentions for air passengers: Evidence from Taiwan. Transportation Research Part A: Policy and Practice, 42 (4), 709-717.

Chen, C.F., \& Chen, F.S. (2010). Experience quality, perceived value, satisfaction and behavioral intentions for heritage tourists. Tourism Management, 31 (1), 29-35.

Chen, C.F., \& Cheng, L. (2012). A study on mobile phone service loyalty in Taiwan. Total quality management and business excellence, 23 (7/8), 807-819.

Chen, C.F., \& Tsai, D.V. (2007). How destination image and evaluative factors affect behavioral intentions? Tourism Management, 28 (4), 1115-1122.

Clemes, M.D., Gan, C., \& Ren, M. (2011). Synthesizing the effects of service quality, value, and customer satisfaction on behavioral intentions in the motel industry: an empirical analysis. Journal of Hospitality 
\& Tourism Research, 35 (4), 530-568.

Croteau, A.M., \& Li, P. (2003). Critical success factors of CRM technological initiatives. Canadian Journal of Administrative Sciences, 20 (1), 21-34.

Del Bosque, I.R. \& Martín, H.S. (2008). Tourist satisfaction a cognitive-affective model. Annals of Tourism Research, 35 (2), 551-573.

Delgado-Ballester, E., \& MunueraAlleman, J.L. (2005). Does brand trust matter to brand equity? Journal of Product and Brand Management, 14 (3), 187-196.

Dick, A.S. \& Basu, D. (1994). Customer loyalty: Toward an integrated conceptual framework. Journal of the Academy of Marketing Science, 22 (2), 99-113.

Flint, D.J., Blocker, C., \& Boutin Jr. P. (2011). Customer value anticipation, customer satisfaction and loyalty: An empirical examination. Industrial Marketing Management, 40 (2), 219-230.

Gallarza, M.G., \& Saura, I.G. (2006). Value dimensions, perceived value, satisfaction and loyalty: an investigation of university students' travel behavior. Tourism Management, 27 (3), 437-452.

Gallarza, M.G., Saura, I.G., \& Garcia, H.C. (2002). Destination image: toward a conceptual framework. Annals of Tourism Research, 29 (1), 56-78.

Gallarza, M.G., Saura, I.G., \& Moreno, F.M. (2013). The quality-value-satisfactionloyalty chain: relationships and impacts. Tourism Review, 68 (1), 3-20.

Giraldi, A., \& Cesareo, L. (2014). Destination image differences between firsttime and return visitors: An exploratory study on the city of Rome. Tourism and Hospitality Research, 14 (4), 197-205.

Gounaris, S. (2005). Trust and commitment influences on customer retention: insights from business-to-business services. Journal of Business Research, 58 (2), 126-140.

Gronroos, G. (2011). A service perspective on business relationships: The value creation, interaction and marketing interface. Industrial Marketing Management, 40 (2), 240-247.

Haemoon, O., \& Kawon, K. (2017). Customer satisfaction, service quality, and customer value; years 2000-2015. International Journal of Contemporary Hospitality Management, 29 (1), 2-29.

Hair, J. F. Jr., Black, W.C., Babin, B. J., \& Anderson, R. E. (2009). Multivariate Data Analysis. 7th Edition, Prentice Hall, Upper Saddle River.

Harris, L.C., \& Goode, M.H. (2004). The four levels of loyalty and the pivotal role of trust: a study of online service dynamics. Journal of Retailing, 80 (2), 139-158.

Homburg, C., Koschate, N., \& Hoyer, W.D. (2006). The role of cognition and affect in the formation of customer satisfaction: A dynamic perspective. Journal of Marketing, 70 (3), 21-31.

Hong, I.B., \& Cho, H. (2011). The impact of consumer trust on attitudinal loyalty and purchase intentions in B2C e-marketplaces: Intermediary trust vs. seller trust. International Journal of Information Management, 31 (5), 469-479.

Hu, H-H., Kandampully, J., \& Juwaheer, T.D. (2009). Relationships and impacts of service quality, perceived value, customer satisfaction and image: an empirical study. The Service Industries Journal, 29 (2), 111-125.

Jones, T., \& Taylor, S.F. (2007). The conceptual domain of service loyalty: how many dimensions? Journal of services marketing, 21 (1), 36-51.

Kandampully, J., \& Hu, H. (2007). Do hoteliers need to manage image to retain 
loyal customers? International Journal of Journal of Quality and Service Sciences, 1 Contemporary Hospitality Management, 19 (6), 435-443. (2), 172-198.

Ladhari, R., Souiden, N., \& Ladhari, I.

Kandampully, J., \& Suhartanto, D. (2000). Customer loyalty in the hotel industry; the role of customer satisfaction and image. International Journal of Contemporary Hospitality Management, 12 (6), 346-351.

Kayaman, R., \& Arasli, H. (2007). Customer based brand equity: evidence from the hotel industry. Managing Service Quality: An International Journal, 17 (1), 92 $-109$.

Keiningham, T.L., Cooil, B., Aksoy, L., Andreassen, T.W., \& Weiner, J. (2007). The value of different customer satisfaction and loyalty metrics in predicting customer retention, recommendation, and share-ofwallet. Managing service quality: An international Journal, 17 (4), 361-384.

Kim, D.J., Ferrin, D.L., \& Rao, H.R. (2008). A trust-based consumer decisionmaking model in electronic commerce: The role of trust, perceived risk, and their antecedents. Decision Support Systems, 44 (2), 544-564.

Kotler, P., \& Armstrong, G. (2013).Principles of Marketing, New Jersey, NJ; Prentice Hall.

Kruja, D., Ha, H., Drishti, E. \& Oelfke, T. (2016).Empowerment in the hospitality industry in the United States. Journal of Hospitality Marketing \& Management, 25 (1), 25-48.

Ladeira, W.J., Santini, F.O., Araujo, C.F., \& Sampaio, H.C. (2016). A meta-analysis of the antecedents and consequences of satisfaction in tourism and hospitality. Journal of Hospitality and Marketing Management, 25 (8), 975-1009.

Ladhari, R. (2009). A review of twenty years of SERVQUAL research. International (2011). Determinants of loyalty and recommendation: The role of perceived service quality, emotional satisfaction and image. Journal of Financial Services Marketing, 16 (2), 111-124.

Lai, F., Griffin, M., \& Babin, B. (2009). How quality, value, image and satisfaction create loyalty at a Chinese telecom. Journal of Business Research, 62 (10), 980-986.

Laroche, M., Habibi, M.R., \& Richard, M.O. (2013). To be or not to be in social media: How brand loyalty is affected by social media? International Journal of Information Management, 33 (1), 76-82.

Lee, H-M., Lee, C-C., \& Wu, C-C. (2011). Brand image strategy affects brand equity after M\&A. European Journal of Marketing, 45 (7/8), 1091 - 1111.

Li, X., \& Petrick, J.F. (2008). Reexamining the Dimensionality of Brand Loyalty: A Case of the Cruise Industry. Journal of Travel \& Tourism Marketing, 25 (1), 68-85.

Loureiro, S.M.C., \& Kastenholz, E. (2011). Corporate reputation, satisfaction, delight, and loyalty towards rural lodging units in Portugal. International Journal of Hospitality Management, 30 (3), 575-583.

Martinez, P., \& del Bosque, I.R. (2013). CSR and customer loyalty: The roles of trust, customer identification with the company and satisfaction. International Journal of Hospitality Management, 35, 89-99.

Morgan, R.M., \& Hunt, S.D. (1994). The commitment-trust theory of relationship marketing. Journal of Marketing, 58 (3), 20 38.

Nadiri, H., Hussain, K., Ekiz, E.H., \& Erdogan, S. (2008). An investigation on the factors influencing passengers' loyalty in the 
North Cyprus national airline. The Total Quality Management Journal, 20 (3), 265280.

Nam, J., Ekinci, Y., \& Whyatt, G. (2011). Brand equity, brand loyalty and consumer satisfaction. Annals of Tourism Research, 38 (3), 1009-1030.

Nghiêm-Phú, B.(2016). Country image, country attachment, country loyalty, and life satisfaction of foreign residents in Vietnam. Tourism and Hospitality Research, 16 (4), 329-344.

Nguyen, N. (2006). The collective impact of service workers and servicescape on the corporate image formation. International Journal of Hospitality Management, 25 (2), 227-244.

Nguyen, N., \& Leblanc, G. (2001). Corporate image and corporate reputation in customers' retention decisions in services. Journal of retailing and consumer Services, 8 (4), 227-236.

Nyadzayo, M.W., \& Khajehzadeh, S. (2016). The antecedents of customer loyalty: A moderated mediation model of customer relationship management quality and brand image. Journal of Retailing and Consumer Services, 30, 262-270.

Nunkoo, R., Teeroovengadum, V., Thomas, P., \& Leonard, L. (2017). Integrating service quality as a second-order factor in a customer satisfaction and loyalty model. International Journal of Contemporary Hospitality Management, 29 (12), 2978-3005.

Oliver, R.L. (1999). Whence consumer loyalty? Journal of Marketing, 63, 33-44.

Olorunniwo, F., \& Hsu, M.K. (2006). A typology analysis of service quality, customer satisfaction and behavioral intentions in mass services. Managing Service Quality: An International Journal, 16 (2), $106-123$.
Pantouvakis, A., \& Lymperopoulos, K. (2008). Customer satisfaction and loyalty in the eyes of new and repeat customers: Evidence from the transport sector. Managing Service Quality: An International Journal, 18 (6), 623 - 643.

Parasuraman, A., Zeithaml, V., \& Berry, L. (1985).A conceptual model of service quality and its implications for future research. Journal of Marketing, 49 (4), 4150.

Parasuraman, A., Zeithaml, V., \& Malhotra, A. (2005). E-S-QUAL: A multiple-item scale for assessing electronic service quality. Journal of Service Research, 7 (3), 213-233.

Petrick, J.F. (2004). The roles of quality, value and satisfaction in predicting cruise passengers' Behavioral Intentions. Journal of Travel Research, 42 (4), 397-407.

Russell-Bennett, R., McColl-Kennedy, J.R., \& Coote, L.V. (2007). Involvement, satisfaction, and brand loyalty in a small business services setting. Journal of Business Research, 60 (12), 1253-1260.

Ryu, K., Lee, H.R., \& Kim, W.G. (2012). The influence of the quality of the physical environment, food, and service on restaurant image, customer perceived value, customer satisfaction, and behavioral intentions. International Journal of Contemporary Hospitality Management, 24 (2), 200-223.

Salegna, G.J., \& Goodwin, S.A. (2005). Consumer loyalty to service providers: An integrated conceptual model. Journal of Consumer Satisfaction, Dissatisfaction and Complaining Behavior, 18, 51-67.

San Martin, H., \& delBosque, I.R. (2008). Exploring the cognitive-affective nature of destination image and the role of psychological factors in its formation. Tourism Management, 29 (2), 263-277.

Sánchez, J.L., Callarisa, L., Rodríguez, 
R.M., \& Moliner, M.A. (2006). Perceived value of the purchase of a tourism product. Tourism Management, 27 (3), 394-409.

Singh, J., \& Sirdeshmukh, D. (2000). Agency and trust mechanisms in relational exchanges. Journal of the Academy of Marketing Science, 28 (1), 150-167.

Singh, A.P., \& Thakur, S. (2012). Impact of Service Quality on Customer Satisfaction and Loyalty: In The Context of Retail Outlets In DB City Shopping Mall Bhopal. International Journal of Management Research and Reviews, 2 (2), 334-344.

Sirdeshmukh, D., Singh, J., \& Sabol, B. (2002). Consumer trust, value and loyalty in relational exchange. Journal of Marketing, 66 (1), 15-37.

Skogland, I., \& Siguaw, J.A. (2004). Are your satisfied customers loyal? Cornell Hospitality Quarterly, 45 (3), 221-234.

Yang, Z., \& Peterson, R.T. (2004).Customer perceived value, satisfaction, and loyalty: The role of switching costs. Psychology and Marketing, 21 (10), 799-822.

Zeithaml, V.A. (1988). Consumer perceptions of price, quality and value: A means-end model and synthesis of evidence. Journal of Marketing, 52 (3), 2-22.

Zeithaml, V., Berry, L., \& Parasuraman, A. (1996). The behavioral consequences of service quality. Journal of Marketing, 60 (2), 31-46. 